DOI: $10.32370 / I A \quad 2021 \quad 1225$

\title{
Interdepartmental Interaction to Combating Against Domestic Violence
}

\author{
Rutian Lesia \\ Postgraduate student \\ Taras Shevchenko National University (Kyiv, Ukraine) \\ ORCID 0000-0001-9609-2381 \\ Chernukha Nadiia \\ Doctor of Pedagogical Sciences, Professor \\ Taras Shevchenko National University (Kyiv, Ukraine) \\ ORCID 0000-0002-5250-2366
}

\begin{abstract}
The role of interdepartmental interaction to combating against domestic violence is described. The need for interdepartmental cooperation in combating against domestic violence is highlighted. Interdepartmental cooperation is considered as a coordinated prevention of domestic violence and ensuring effective and practical realization of the rights of victims. Aspects (appearance, meaning, process, result) of domestic violence are described. It is stated that the act of domestic violence is a planned, conscious, controlled process. It is proved that in accordance with international standards and domestic legislation, interdepartmental cooperation is carried out both in the field of prevention and combating domestic violence. A socio-pedagogical model of domestic violence prevention is developed. The use of the model makes it possible to describe not only the long-term relationships between its components, but also to determine the potential ability of individual components in the future to restore equilibrium. In general, the developed socio and pedagogical model of prevention of domestic violence will effectively to combating against domestic violence and its recurrence. Presented analysis demonstrates the benefits of comprehensively reflecting the interagency relationships between different organizations and victims of domestic violence.

Key words: violence, domestic violence, hierarchy of the domestic violence process, socio and pedagogical model of domestic violence prevention.
\end{abstract}

Актуальність дослідження. Домашнє насильство є одним 3 найбільш поширених і незаконних дій в усьому світі, оскільки, у кожній країні є люди, які безпосередньо відчули на собі наслідки домашнього насильства, зокрема через існування культу насильства у сучасному суспільстві.

Результати проведеного нами теоретичного аналізу проблеми дають нам підстави стверджувати, що домашнє насильство - це випадки порушення прав, безпеки і свободи іншої людини. Наразі науковці виділяють здебільшого два основні види домашнього насилля: психологічне і фізичне. Психологічне насильство має на меті контролювання думок, вчинків, життєвих цінностей іншої людини. Такий вид насильства 
часто залишається непомітним у сучасному суспільстві. Більшість сімей не усвідомлюють, що по відношенню до них відбувається насильство, а відтак, про такі випадки повідомлення до органів внутрішніх справ не надходять. Це репрезентує відсутність сформованої правової компетентності жертви домашнього насильства. Фізичне насильство передбачає звернення щодо його скоєння і $€$ більш розповсюдженими.

Варто зазначити, що діяльність кривдників стосовно їх жертв має негативну спрямованість і в переважній більшості проявляється у реалізації ними певних обмежень, утисків, тиску. Наприклад, ізоляція, економічні маніпуляції, примус, залякування i погрози, емоційне насильство, словесні образи, переслідування, фізичне насильство над діями особи, сексуальне насильство (згвалтування), що в подальшому може призвести до суїциду жертви одного (або декількох) з зазначених обмежень [4].

Сучасна статистика засвідчує, що насильство є причиною знищення тисяч родин. На жаль, насильство у родинах залишається і досі великою бідою українського суспільства. Точна кількість жінок, які постраждали чи зараз страждають від домашнього насильства, невідома. Проте, за 2020 рік в Україні за домашнє насильство засуджено 921 осіб. У порівнянні із 2019-м роком вироків було вчетверо менше (225 випадків). Ці статистичні дані свідчать про те, що кривдники все частіше несуть юридичну відповідальність за свої протиправні, злочинні дії. Незважаючи на це, тривожним фактом є те, що 44 \% українців знають про домашнє насильство із власного досвіду [3].

Репрезентовані вище статистичні показники дають змогу констатувати, що державна політика щодо боротьби з домашнім насильством, зокрема прийняття у 2016 р. Закону України «Про протидію домашньому насильству» розглядається важливим сегментом розвитку українського суспільства та забезпечення якості життя кожного його члена.

Метою статmі є дослідження та аналіз ролі міжвідомчої взаємодії у боротьбі 3 домашнім насильством.

Відповідно до поставленої мети визначено завдання дослідження: виокремити необхідність міжвідомчої взаємодії у боротьбі з домашнім насильством; розробити соціально-педагогічну модель профілактики домашнього насильства. 
Виклад основного матеріалу. Зазначимо, що домашне насильство вивчали зарубіжні вчені та правозахисники, зокрема Дж. Коннорс, Р. Кук, Р. Севал, Е. Бернес, Х. Пиєтіле, К. Бартлет та ін. В українському науковому обігу дослідження цієї проблематики здійснювали А. Блага, В. Голіна, К. Левченко, А. Ноур, О. Руднєва, Г. Христова, А. Капська, Ж. Петрочко, О. Зверєва, Н. Жигайло, М. Козирєв, І. Богданова, В. Грищук, Н. Гуторова, Н. Чернуха.

Всебічний аналіз насильства в сім’ї, здійснений науковцями в педагогіці, психології, кримінології, соціології та філософії дозволяє визначити наступні його характеристики: «силовий вплив (включаючи психічний і моральний) однієї людини на іншу, який проявляється шляхом застосування сили; примушений контроль» (Ю. Щербак); «насильство - застосування фізичної сили для досягнення будь-чого» (В. Яременко та О. Сліпушко) або насильство розуміється як «застосування сили проти людини» (С. Дев’яткін); «насильство є чинником примушеного контролю, що практикує одна людина над іншою» (В. Оржеховська), або насильство - це «будь-який вплив на людину, включаючи психічний i моральний, що відбувається проти іiі волі» (С. Дев’яткін); «застосування або загроза застосування сили у прямій або непрямій формі 3 метою примушення людини до певної поведінки; є циклом фізичної, вербальної, духовної та економічної образи, яка повторюється з метою влади й контролю однієї особи над іншою» (О. Фролова); «взаємозв’язок індивідуально-психологічних характеристик, агентів насилля та об’єктивних умов їх життєдіяльності, і прагнення індивідів мати певні можливості з метою перетворення свого оточення» (В. Бодров); «співвідношення біологічних і соціальних факторів у здійсненні насильницьких дій, яке полягає у наявності спадкових нахилів до насильства, реалізація або не реалізація яких залежить від умов соціального середовища, що детермінують цей процес, та від характеру самоусвідомлення їх людиною» (С. Фуркало); «цикл фізичної, сексуальної, вербальної, емоційної та економічної наруги щодо близьких людей 3 метою встановлення над ними влади й контролю, який має повторювальний характер та наростаючу частоту» (І. Кльоцина).

Першим з дослідників, який зацікавився проблемою агресії, став 3. Фройд, який вважав, що агресивність по суті може бути не реакцією на подразнення, а є постійно присутнім в організмі імпульсом, зумовленим природою людини (3. Фройд, 2002). 
Взаємозв'язок агресивної поведінки та насильства розкривається у роботах Е. Фромма (1997; 1998). Дослідження процесу соціального научіння, проведені Р. Бероном і Д. Річардсон, довели, що специфічний характер міжособистісної взаємодії в сім'ях призводить до поступового засвоєння і закріплення агресивних стереотипів поведінки, який повторюється у різноманітних ситуаціях міжособистісної взаємодії. Беручи до уваги теорію соціального научіння, А. Бова, І. Грабська, О. Шинкаренко визначають три підходи до проблеми насильства в сім’ї: соціально-історичний, системно-сімейний та індивідуально-психологічний [6, с. 176].

За Я. Юрків, домашнє насильство - це певні свідомі дії одного члена сім’ї стосовно іншого, якщо ці дії порушують конституційні права й свободи члена сім’ї як громадянина та завдають шкоду його фізичному, психічному або моральному здоров’ю, а також розвитку дитини $[14 ; 15]$.

Своєю чергою, С. Шаргородська доводить, що домашнє насильство - певні свідомі дії одного члена сім’ї (партнера) проти іншого члена сім’ї (партнера), які порушують права і свободи людини, завдають шкоди фізичному, психічному, економічному, сексуальному благополуччю, а також розвитку дитини [16].

Наголосимо, що логіка викладу матеріалу у статті потребує розгляду змісту та структури міжвідомчої взаємодії у боротьбі з домашнім насильством.

Домашнє насильство є процесом зазіхання на здоров'я, безпеку, свободу і життя іншої людини, що може включати наступний алгоритм домашнього насильства, так і як: поява агресії, сенс, процес насильства і його результат (Рис. 1).

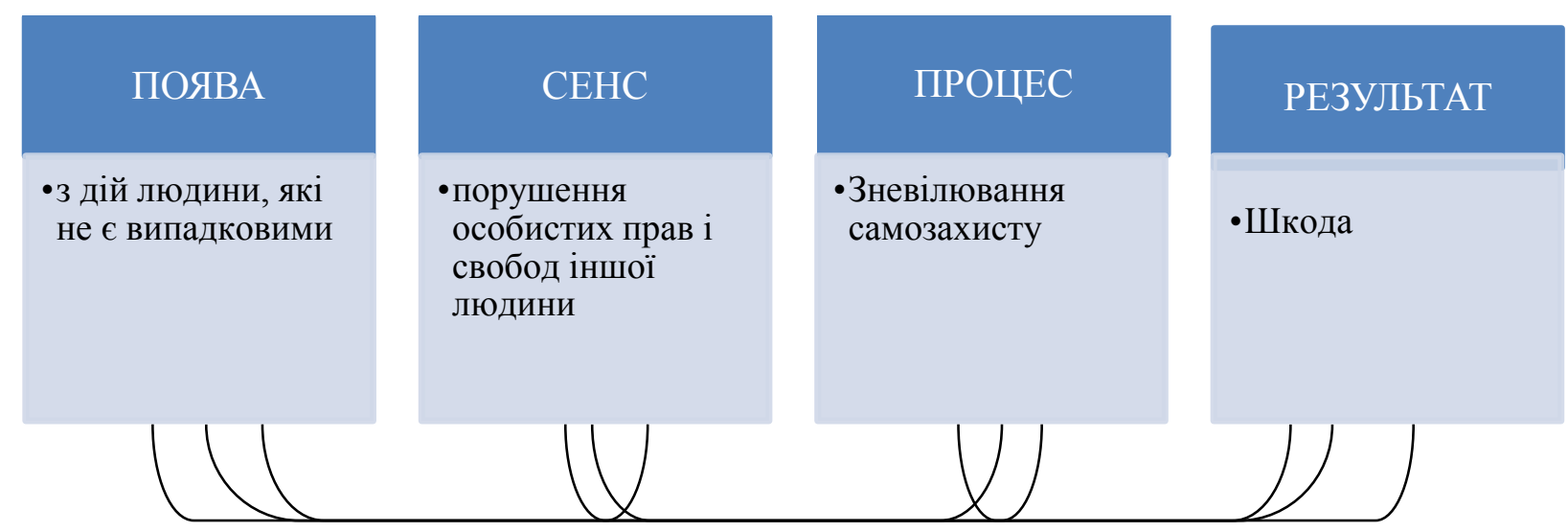

Рис. 1. Алгоритм процесу домашнього насилля. Джерело: складено автором. 
Варто зауважити, агресія з'являється як з контрольованих людиною дій, так і не 3 контрольованих нею дій. Слід зважати на те, що «сенс» насильства полягає в усвідомленому порушенні особистих прав і свобод конкретної людини. Процес насильства зневільовує можливий самозахист жертви домашнього насилля. Основною характеристикою цього аспекту є асиметрія сил, коли одна сторона має переваги над іншою, і результатом будь-якого акту насильства є спричинена навмисно шкода [5; 7; 8].

Враховуючи різні види домашнього насильства (психологічне, економічне, сексуальне, фізичне тощо), одним із дієвих шляхів його попередження є міжвідомча взаємодія у боротьбі з домашнім насильством [10].

Для окреслення важливості ролі міжвідомчої взаємодії у боротьбі з домашнім насильством нами розроблено соціально-педагогічну модель профілактики домашнього насильства, метою якої є зменшення кількості випадків домашнього насильства, його попередження шляхом проведення тренінгів для жінок, а також створення i розповсюдження соціально-профілактичних матеріалів, які висвітлюють проблеми домашнього насильства (Рис. 2).

Дана модель демонструє можливі шляхи міжвідомчої взаємодії всіх установ у боротьбі з домашнім насильством. Міжвідомча взаємодія повинна забезпечити надання ряду послуг для жертв домашнього насилля, такі як: медичні послуги, інформаційні, соціальні, правові тощо. Через що, наразі потребують підвищення якості послуг кваліфікованих психологів, юристів і соціологів.

Суттєву i важливу роль у міжвідомчій взаємодії щодо попередження домашнього насильства відіграють соціальні служби, зокрема працівники центру соціальних служб, які аналізують звернення потерпілих і проводять початкову оцінку життєдіяльності сім’і, уточнюють (у разі потреби) інформацію в інших відомствах, визначають доцільність та можливість подальшої роботи із сім'єю та її членами у межах компетенції Центру.

Варто зважити на те, що місце правоохоронних органів у міжвідомчій взаємодії $є$ беззаперечно одним із найважливіших, адже саме вони приймають та розглядають заяви про домашнє насильство у сім’ї або загрозу його виникнення, а при отриманні заяви, повідомлення чи іншої інформації про факт вчинення насильства в сім’ї вживають 
передбачених законом заходів щодо припинення правопорушення. Своєю чергою, міжвідомча взаємодія, відповідно до розробленої соціально-педагогічної моделі профілактики домашнього насильства, у боротьбі 3 домашнім насильством може реалізовуватися на всіх можливих рівнях (Рис. 2).

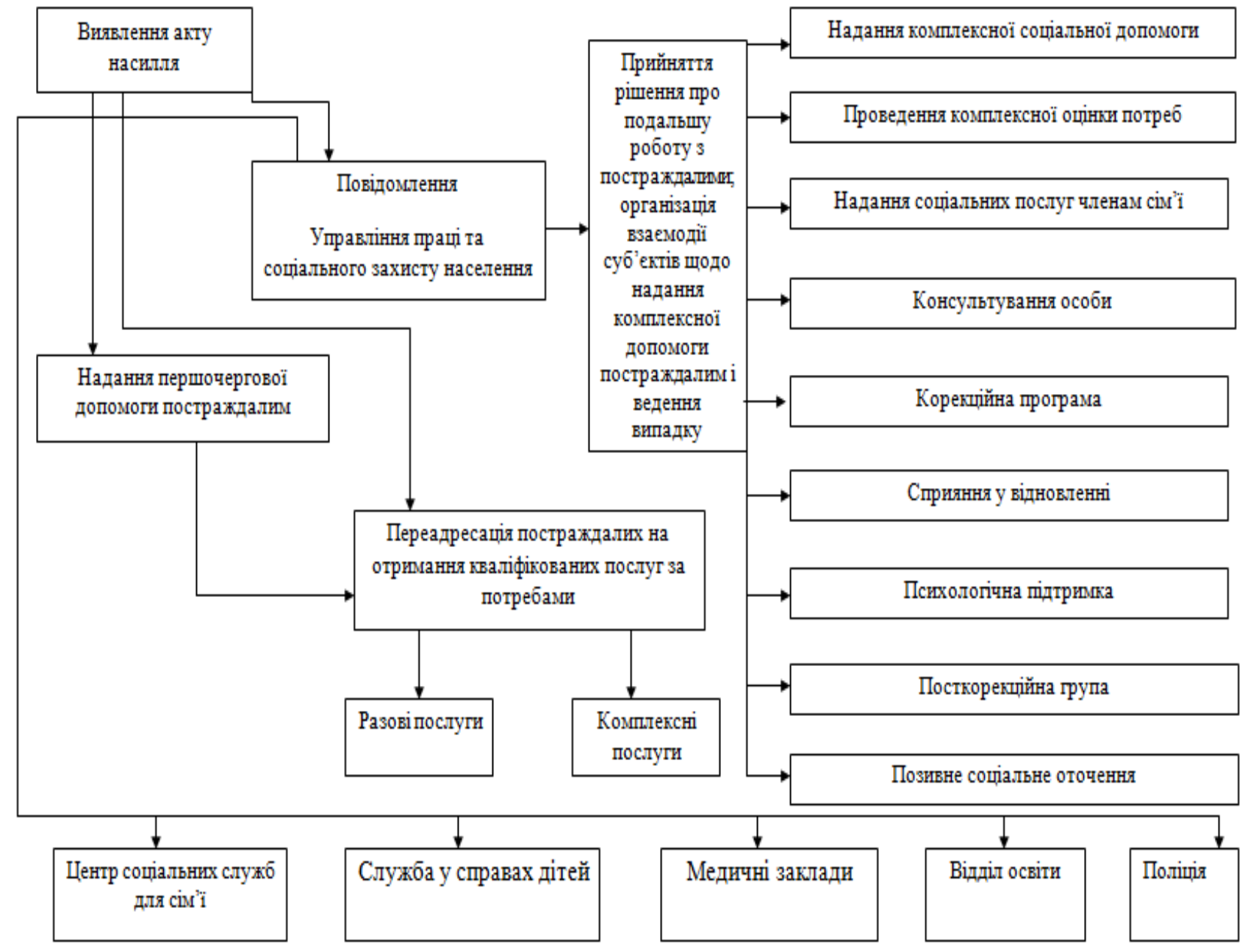

Рис. 2. Соціально-педагогічна модель профілактики домашнього насильства. Джерело: складено автором.

Наприклад, на місцевому рівні відбувається координація інформаційнопросвітницьких заходів шляхом неформальної освіти, розроблення пропозицій щодо вдосконалення законодавства та практики його застосування місцевими координаційними радами, до складу яких повинні входити представники різних сфер суспільства, такі як представники органів місцевого самоврядування, прокуратури, суду, представники громадських об’єднань, релігійних організацій, міжнародних та іноземних неурядових організацій тощо. 
Висновок. Отже, у сучасному українському суспільстві, зокрема, у сфері соціальної роботи, міжвідомча взаємодія наразі $є$ одним із пріоритетів забезпечення якості життя. Відповідно, у соціально-педагогічній практиці щодо профілактики домашнього насильства механізми міжвідомчої взаємодії незаперечно відіграють суттєву роль у попередженні домашнього насильства та створенні безпечного середовища, життєвого простору для кожної особистості.

Тому, результатом міжвідомчої взаємодії буде формування дієвої, ефективної системи невідкладної допомоги і захисту жертв домашнього насильства. Саме міжвідомча взаємодія надасть можливість створити ефективну систему профілактики домашнього насильства, що зведе нанівець негативний вплив і наслідки домашнього насильства. Міжвідомча взаємодія у процесі ліквідування домашнього насильства визначає необхідні потреби жертв і розробляє, впроваджує виконання індивідуальних програм реабілітації жертв.

\section{References}

1. Bova A. A. Model faktoriv, shho obumovlyuyut nasylstvo v simyi [Model of factors that cause domestic violence]. Ukrayinskyj socium, 2005. No. 1. Pp.15-25.

2. Beron R., Rychardson D. Agressiya [Aggression]. Seriya «Mastera psyhologii», Piter, 2001. 352 p.

3. Domashnye nasylstvo v Ukrayini : skilky v krayini zhertv i shho zagrozhuye

kryvdnykam [Domestic violence in Ukraine: how many victims there are in the country and what threatens the perpetrators]. URI : https://ukr.segodnya.ua/ukraine/domashnee-nasilie-vukraine-kto-stanovitsyazhertvami-i-chto-grozit-obidchikam-1099013.html

4. Konvenciya Rady Yevropy pro zapobigannya nasylstvu stosovno zhinok $i$ domashnomu nasylstvu ta borotbu z cymy yavyshhamy [Council of Europe Convention on Preventing and Combating Violence against Women and Domestic Violence]. 2013. URI : https://rm.coe.int/1680096e45

5. Metodychnyj posibnyk dlya faxivciv, yaki vprovadzhuyut korekcijni programy dlya osib, yaki vchynyly nasylstvo v simyi [A Guide for Professionals Implementing Correctional Programs for Persons Who Have Committed Domestic Violence]. 2011. URI : https://www.osce.org/files/f/documents/6/4/93318.pdf

6. Nesterchuk V. V. Domashnye nasylstvo nad zhinkamy yak obyekt sotsialnoyi roboty [Domestic violence against women as an object of social work]. Dukhovnist osobystosti: metodolohiya, teoriya i praktyka. 2019. Issue. 5 (92). Pp. 172-183.

7. Pet'ko L. V. Vyvchennya hendernykh roley ta vzayemovidnosyn u simyi zi studentamy VNZ na praktychnykh zanyattyakh $z$ inozemnoyi movy [Studying of gender roles and relationships in the family with university students in foreign language practical classes]. Naukovyy chasopys NPU imeni M.P.Drahomanova. Seriya 11. Sotsialna robota. Sotsialna 
pedahohika: zb. nauk. prats [za red. A.Y.Kaps'koyi]. Issue 14 (Part II). Kyyiv : Vyd-vo NPU imeni M.P. Drahomanova. 2012. Pp. 112-123. URI

http://enpuir.npu.edu.ua/handle/123456789/7871

8. Pet'ko L. V. Vykhovnyy potentsial metodu sytuatsiynoho analizu («Case study» method) u formuvanni profesiyno oriyentovanoho inshomovnoho navcha'noho seredovyshcha $v$ umovakh universytetu [Educational potential of the case study method in the formation of professionally oriented foreign language learning environment in the conditions of university]. Naukovyy chasopys NPU imeni M.D.Drahomanova. Seriya 17. Teoriya i praktyka navchannya ta vykhovannya : zb. nauk. pr. Kyiv : Vyd-vo NPU imeni M.P.Drahomanova, 2015. Issue 27. Pp. 133-140.

9. Pet'ko L. V. Philosophical and linguistic ideas of understanding interpersonal communication in the social environment [Philosophical and linguistic ideas of interpersonality communication in professional sphere]. Naukovi zapysky NaUOA. Ostrog : Vyd-vo «Ostroz'ka akademija», 2015. Serija «Filologichna». Issue 53. Pp. 353-356.

10. Protydiya domashnomu nasylstvu: realiyi $i$ perspektyvy [Combating domestic violence: realities and prospects]: Zbirnyk tez Oblasnoyi naukovo-praktychnoyi konferenciyi. Chernigiv, 2019. $126 \mathrm{p}$.

11. Sotsialna robota: realii ta vyklyky chasu [Social work: realities and challenges of time]: navchalno metodychnyi posibnyk / S. O. Omelchenko [ta in.]. Sloviansk : Vyd-vo B. I. Matorina, 2021.219 p.

12. Chernukha N. M., Huk O. F. Sotsialne vykhovannya u suchasnomu ukrayinskomu sotsiumi : realiyi, dosvid, perspektyvy [Social education in modern Ukrainian society: realities, experience, prospects]. Naukovyy chasopys Natsional'noho pedahohichnoho universytetu imeni M. P. Drahomanova. Seriya 11 : Sotsialna robota. Sotsialna pedahohika : zb. nauk. prats. Kyiv: Vyd-vo NPU imeni M. P. Drahomanova, 2018. Issue 24 (Tom 2). Pp. 153-158.

13. Chernukha N. Humanitarna osvita: umovy dlya formuvannya tolerantnosti osobystosti [Humanitarian education: conditions for the formation of personal tolerance]. Visnyk Luhans'koho natsional'noho universytetu imeni Tarasa Shevchenka. Pedahohichni nauky. 2012. No. 22(2). Pp. 80-84.

14. Yurkov J. I. Sutnist ta zmist sotsialnoho fenomenu «nasylstvo v simi» [The essence and content of the social phenomenon "domestic violence"]. Scientific Bulletin of Uzhhorod National University. Series "Pedagogy, social work", 2013. No. 27. Pp. 234-237.

15. Nasylstvo ditei u simi yak sotsialno-pedahohichna problema [Violence of children in the family as a socio-pedagogical problem].. Naukovyi visnyk Uzhhorodskoho un-tu: Seriia: Pedahohika. Sotsialna robota. Uzhhorod : Hoverla, 2013. Issue 28. Pp. 185-189 p.

16. Sharhorodska S. Nasyllya v simyi : vydy, naslidky, shlyakhy podolannya [Domestic violence: types, consequences, ways to overcome]. Sotsialnyy pedahoh. 2007. No. 2. Pp. 14-16.

17. Kostenko D., Karam Ah., Honchar L., Ternopilska., Chernukha N. Cross-cultural competence of personality and adaptation to polycultural environment: approaches and techniques. Intellectual Archive. Toronto: Shiny Word.Corp. (Canada). 2019. Vol. 8 (October/December). No. 4. Pp. 338-357. https://doi.org/10.32370/IA_2019_12_25

18. Chernukha N., Vasylieva-Khalatnykova M., Tokaruk L. The technology for forming 
professional reflection in future Social work educators in a higher educational institution. Intellectual Archive. Toronto: Shiny Word Corp. (Canada). 2018. (November/December). Vol. 7. No. 6. PP. 99-108. https://doi.org/10.32370/2018_11_12

Translation of the Title, Abstract and References to the Author's Language

\section{УДК 364.65}

\section{насильством. \\ Рутьян Л. Г., Чернуха Н. М. Міжвідомча взасмодія у боротьбі $з$ домашнім}

Охарактеризовано роль міжвідомчої взаємодії у боротьбі 3 домашнім насильством. Обгрунтовано необхідність міжвідомчої взаємодії у боротьбі з домашнім насильством. Розглянуто міжвідомчу взаємодію як скоординоване запобігання домашньому насильству і забезпечення ефективної та практичної реалізації прав постраждалих осіб. Описано аспекти домашнього насильства, такі як: поява, сенс, процес, результат. Констатовано, що акт домашнього насильства - це спланований, усвідомлений, контрольований процес. Доведено, що відповідно до міжнародних стандартів та вітчизняного законодавства міжвідомча взаємодія здійснюється як у сфері запобігання, так і у сфері протидії домашньому насильству. Розроблено соціальнопедагогічну модель профілактики домашнього насильства. Застосування моделі дало змогу описати не тільки довгострокові взаємозв' язки між їі компонентами, а й визначити потенційну здатність окремих компонентів у перспективі до відновлення рівноваги. Розроблена соціально-педагогічна модель профілактики домашнього насильства сприятиме ефективному протистоянню домашньому насильству i його рецидивам. Проведений аналіз демонструє переваги комплексного відображення міжвідомчих взаємозв’язків між різноманітними організаціями і жертвами домашнього насильства.

Ключові слова: насильство, домашнє насильство, ієрархія процесу домашнього насилля, соціально-педагогічна модель профілактики домашнього насильства.

\section{Література}

1. Бова А. А. Модель факторів, що обумовлюють насильство в сім'ї. Украӥнський сойiys, 2005. № 1. С. 15-25.

2. Бэрон Р., Ричардсон Д. Агрессия. Серия «Мастера психологии». Питер, 2001. 352 с.

3. Домашнє насильство в Україні: скільки в країні жертв і що загрожує кривдникам. URI : https://ukr.segodnya.ua/ukraine/domashnee-nasilie-v-ukraine-ktostanovitsyazhertvami-i-chto-grozit-obidchikam-1099013.html

4. Конвенція Ради Європи про запобігання насильству стосовно жінок i домашньому насильству та боротьбу з цими явищами. URI : https://rm.coe.int/1680096e45

5. Методичний посібник для фахівців, які впроваджують корекційні програми для осіб, які вчинили насильство в сім’ї. URI :

https://www.osce.org/files/f/documents/6/4/93318.pdf

6. Нестерчук В. В. Домашнє насильство над жінками як об'єкт соціальної роботи. Духовність особистості: методологія, теорія $i$ практика. 2019. Вип. 5 (92). C. $172-183$.

7. Петько Л. В. Вивчення гендерних ролей та взаємовідносин у сім'ї зі студентами ВНЗ на практичних заняттях з іноземної мови / Л.В.Петько // Науковий часопис НПУ 
імені М.П.Драгоманова. Серія 11. Сочіальна робота. Сочіальна педагогіка: зб. наук. праць [за ред. А. Й. Капської]. Вип. 14 (частина II). Київ : Вид-во НПУ імені М. П. Драгоманова. 2012. С. 112-123. URI http://enpuir.npu.edu.ua/handle/123456789/7871

8. Петько Л. В. Виховний потенціал методу ситуаційного аналізу (“Case study” method) у формуванні професійно орієнтованого іншомовного навчального середовища в умовах університету. Науковий часопис НПУ імені М. Д. Драгоманова. Серія 17. Теорія і практика навчання та виховання : зб. наук. пр. ; за ред. академіка В. І. Бондаря. Київ : Вид-во НПУ імені М. П. Драгоманова, 2015. Вип. 27. С. 133-140.

9. Петько Л. В. Філософсько-лінгвістичні ідеї розуміння міжлюдської комунікації у соціальному середовищі. Наукові записки Національного університету «Острозька академія». Серія «Філологічна» : зб. наук. праць / укл. І. В. Ковальчук, Л. М. Коцюк, С. М. Новоселецька. Острог: Вид-во Національного ун-ту «Острозька академія», 2015. Вип. 53. С. 309-312.

10. Протидія домашньому насильству: реалії і перспективи : збірник тез Обласної науково- практ. конф. Чернігів : ЧНТУ, 2019. 126 с.

11. Соціальна робота: реалії та виклики часу: навчально методичний посібник / С. О. Омельченко [та ін.]. Слов’янськ : Вид-во Б. І. Маторіна, 2021. 219 с.

12. Чернуха Н. М., Гук О. Ф. Соціальне виховання у сучасному українському соціумі : реалії, досвід, перспективи. Науковий часопис Національного педагогічного університету імені М. П. Драгоманова. Серія 11 : Соціальна робота. Соціальна педагогіка : зб. наук. праць. Київ : Вид-во НПУ імені М. П. Драгоманова, 2018. Вип. 24 (том 2). С. 153-158.

13. Чернуха Н.М. Гуманітарна освіта: умови для формування толерантності. Вісник Луганського національного університету імені Тараса Шевченка. Педагогічні науки. 2012. № 22(2). С. 80-84.

14. Юрків Я. І. Сутність та зміст соціального феномену «насильство в сім’ї». Науковий вісник Ужгородського національного університету. Серія «Педагогіка, соціальна робота», 2013. № 27. С. 234-237.

15. Юрків Я. І.Насильство дітей у сім’і як соціально-педагогічна проблема. Науковий вісник Ужсгородського університету: Серія: Педагогіка. Соціальна робота. Ужгород : Говерла, 2013. Вип. 28. С. 185-18

16. Шаргородська С. Насилля в сім’ї : види, наслідки, шляхи подолання. Сочүіальний педагог, 2007. № 2. С. 14-16.

17. Kostenko D., Karam Ah., Honchar L., Ternopilska., Chernukha N. Cross-cultural competence of personality and adaptation to polycultural environment: approaches and techniques. Intellectual Archive. Toronto: Shiny Word.Corp. (Canada). 2019. Vol. 8 (October/December). No. 4. Pp. 338-357. https://doi.org/10.32370/IA_2019_12_25

18. Chernukha N., Vasylieva-Khalatnykova M., Tokaruk L. The technology for forming professional reflection in future Social work educators in a higher educational institution.. Intellectual Archive. Toronto: Shiny Word Corp. (Canada). 2018. (November/December). Vol. 7. No. 6. Pp. 99-108. https://doi.org/10.32370/2018_11_12 